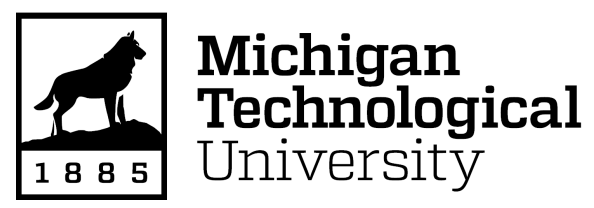

Michigan Technological University Digital Commons@ Michigan Tech

5-31-1969

\title{
Community Relationships and Population Dynamics of Terrestrial Mammals of Isle Royale, Lake Superior, 1968-1969
}

Wendel J. Johnson

Purdue University

Michael L. Wolfe Jr.

Purdue University

Durward L. Allen

Purdue University

Follow this and additional works at: https://digitalcommons.mtu.edu/wolf-annualreports

\section{Recommended Citation}

Johnson, Wendel J.; Wolfe, Michael L. Jr.; and Allen, Durward L., "Community Relationships and Population Dynamics of Terrestrial Mammals of Isle Royale, Lake Superior, 1968-1969" (1969). Ecological Studies of Wolves on Isle Royale. 53.

10.37099/mtu.dc.wolf-annualreports/1968-1969 
COMMNITY RELATIONSHIPS AND POPULATION DYNAMICS

OF TERRESTRIAL MAMAIS OF ISIE ROYAIE, IALE SUPERIOR*

\author{
Third Annual Report \\ (Covering the eleventh year in the Isle Royale studies)
}

$1968-69$

Wolf nos.
min. 15
tmit ast $=16(-17)$

by

Wendel J. Johnson, Graduate Research Assistant

Michael L. Wolfe, Jr., Research Associate

Durward L. Allen, Professor of Wildlife Ecology

Department of Forestry and Conservation Purdue University

Lafayette, Indiana 47907

31 May 1969

*Receiving principal support during the current year from the National science Foundation (GB-5124), the National Park Service, and the Wildlife Management Institute. 


\section{MAMMAL POPULATIONS OF ISIE ROYALE}

During the past year important progress was made in summarization and interpretation of information from the long-term study, and Michael Wolfe finished the aging of nearly 300 moose molar-tooth specimens collected in the work of the pest ten years. In October, Wendel Johnson terminated field work on the small manmal popalations of the island and is currently working on his thesis. He expects to complete the project in August. Wolfe plans to continue his post-doctoral assignment on the wolf and moose for a third year-- through June, 1970 .

In 1968, Wolfe and Johnson began the spring field period on May 6 . Since a housing shortage prevented our having two families on the island for the summer, Wolfe returned to the campus on May 25 to continue the work on moose teeth. Summer assistants Michael J. Doskocil, John A. Coble, and John C. Keeler arrived on RANGER III on June 11. Coble spent three weeks on moose-wolf work and left at the end of June. The Johnsons and the two undergraduates occupied Bangsund Cabin, with Keeler departing on August 27 and Doskocil on September 5. Allen spent a week on Isle Royale in late May and early June.

Wolfe returned to the field for most of September and October, assisted by Larry J. Roop from October 5 to 24 . The summer period terminated on october 31, when Wolfe and Johnson returned to the campus.

In 1969 it was our plan to begin the winter study a week early, but unfavorable weather delayed the party in Virginia, Minnesota, the flight to the island finally being made on January 3l. Allen flew back to the mainland on February 22. Our connection flights were again made by William J. Martila. Donald E. Murray continued as our field pilot, this being the eleventh year in which he has been a member of the winter research team. Members of the park staff who participated in the winter work were Richard W. Igo, Donald S. Anderson, and Warner M. Forsell.

Several publications are now in preparation by present and former project personnel, and this will be a point of emphasis in the year ahead. Two short papers on this work were published recently as follows:

Wolfe, Michael L., Jr. 1969. Age determination in moose by cemental layers of molar teeth. Jour. Wildl. Mgmt. 33(2):428-431.

Karns, Patrick D. and Peter A. Jordan.' 1969. Pneumostrongylus tenuis in moose on a deer-free island. Jour. Wildl. Mgmt. 33(2):431-433.

A feature of the winter study period in 1969 was the presence of a television crew representing a combined project of the Canadian Film Board and the Documentary Division of MGM. All of the photography was done by William $C$. Mason, CFB, who arrived on the island February 6 . Don Murray contracted his Supercub to this group, with Donald E. Glaser as pilot, who arrived on the same date. Irwin Rosten, of MGM, joined the field party (via Matila) on February 8 , and Dan Iindquist brought in a helicopter from Duluth on February 12 . Extra gas for the chopper was flown in, three barrels at a time, by Northern Airways, 
of Fort William. Rosten left on the 12th and Mason, Glaser, and Lindquist on the 18 th.

The two weeks of television shooting was characterized by the best stretch of weather we have known in at least three years. The principal efforts of the research crew (Wolfe, Murray, Anderson, Allen) during this period were devoted to locating wolves and expediting the photography. The TV documentary on the wolf, of which the Isle Royale sequences will be a part, is expected to be on one of the major networks next fall.

\section{Winter Conditions, 1969}

The most singular aspect of weather during the 1969 winter study period was the deep and heavy snow cover. Average depth in the woods at Windigo upon our arrival ( 31 January) was 44 inches, represents the greatest snow accumulation recorded since this work began in February, 1959. The measured water content of the snow varied from 17 to 35 percent by volume from top to bottom of the snow profile. It is our subjective opinion that the nature of this snow cover may have presented the heavier moose with a mobility problem while, at the same time, affording the wolves relatively easy footing. It is interesting to note that the snow depth at the extreme northeast end of the island was approximately 12-15 inches less than at the southwest end. Less than six inches of new snow fell during February and early March, and by the time winter operations were terminated on 14 March snow cover at Windigo had settled to 32.1 inches.

Temperatures were quite similar to those recorded for the previous winter. The mean daily minimum and maximum figures for the six-week period were $+4.5^{\circ} \mathrm{F}$. and 28. $0^{\circ}$ F., respectively. Shelf ice and ice between the island and the north shore of Lake Superior was poorly developed at the time of our arrival. Continuous ice between Isle Royale and Canada formed by the aggregation of floating pieces and sheets during the first ten days of February. However, there were persistent leads of open water, and winds broke the ice up by the end of the month.

In general flying conditions were more favorable this winter than in 1968. The incidence of days "too windy to fly" was considerably less than last winter, but the total number of hours flown (131) was well below the average for other years. This was primarily the result of a week's delay in our move to the island due to snowstorms in Minnesota. Tracking conditions deteriorated progressively during the latter half of the study because of the absence of fresh snow.

Seed-eating birds were rare this winter, evidently because of the great scarcity of foods of this kind. There was no mountain ash fruit, and seeds were completely missing from the birch trees. It is possible that an early winter ice storm accounted for this in part, although there was no direct evidence. We made no observations of small fringillids-- the siskins and redpolls that usually are abundant when birches seed heavily. There were no snowy owl observations, but one great horned owl and an immature bald eagle were seen. 
The Mose Population

June observations of moose cows with calves are not representative of the calving rate because many of the young are hidden at this early stage of their development. Mid-summer counts are better, but in 1968 the number of observations was inadequate to give a reliable cow-calf ratio. However, Wolfe and Martila made the usual late october aerial survey of the moose herd, and their findings on sex-age distribution are summarized in Table 1.

Table 1. Moose herd composition from aerial survey, October 1968.

\begin{tabular}{llcccc} 
Males & Females & Calves & Total & $\begin{array}{c}\text { Cows w/ } \\
\text { calves }\end{array}$ & $\begin{array}{c}\text { Cows w/ } \\
\text { twins }\end{array}$ \\
\hline 13 & $\frac{23}{43}$ & $\frac{29}{7}$ & $\frac{1}{233}$ & &
\end{tabular}

The above figures indicate a ratio of 56 calves per 100 females. In a composition count made in late February and early March, 55 moose were classified as cows and 21 of these were accompanied by one or more calves, giving a ratio of 38 calves per 100 cows. At that time calves constituted 20 percent of the total moose population (based on a sample of 106 carefully checked observations). The high incidence of young animals may help to account for the high kill of calves by wolves during this winter.

Moose numbers and winter distribution

The distribution of moose during the winter was similar to that observed in other years of deep snow cover, except that locally the effects of snow depth appeared to be intensified. Large open areas in the mid-portion of the island were nearly without tracks in February-- a marked contrast with last year when moose were pawing through less than a foot of snow to feed on the ground vegetation of these sites. This year feeding moose evidently found the best footing on the edges of lakes and wind-blown ridgetops where they were commonly seen, in contrast to the paucity of tracks in adjacent areas (especially the lee slopes of ridges) of deep snow. More information on moose distribution should be available after the pellet-plot lines are monitored in the spring.

It appeared that the heavy snow supported moose at a higher level than in other years, since the animals were commonly seen "reworking" the browse line previously established on balsam trees. In contrast with last winter, small balsams had only their tops exposed, and lower branches were completely protected by the deep snow.

Results of the 1969 aerial moose census are shown in Table 2. Previous annual reports have described the statistical principles and mechanical aspects of the procedure employed. The calculated estimate of 1150 moose with 95 percent confidence limits of plus or minus 266 represents the highest population figure for the Isle Royale moose herd obtained to date during the current series of investigations. It is probeble that the tendency of moose to feed on the edges 
of water areas and ridgetop openings contributed to an unusually high degree of visibility this year. As an indication of this, in a flight of one hour that traversed most of the length of the island, Allen counted 33 moose-- the most observed by him in such a flight in nine winters. The count included a concentration of 12 moose along the crest and south slope of Beaver Island. This was also the largest number ever seen in this location, which is under frequent surveillance every winter.

Table 2. 1969 winter aerial census of moose

\begin{tabular}{|c|c|c|c|c|c|c|}
\hline Stratum & $\begin{array}{c}\text { Area } \\
(\mathrm{sg} . \mathrm{mi} .)\end{array}$ & Plots & $\begin{array}{l}\text { Percent of } \\
\text { stratum }\end{array}$ & $\begin{array}{l}\text { Moose } \\
\text { counted }\end{array}$ & $\begin{array}{l}\text { Moose per } \\
\text { sq. mi. }\end{array}$ & $\begin{array}{c}\text { Calculated } \\
\text { total }\end{array}$ \\
\hline $\begin{array}{l}1 \\
2 \\
3 \\
4\end{array}$ & $\begin{array}{l}54.25 \\
47.04 \\
76.41 \\
35.05\end{array}$ & $\begin{array}{r}8 \\
14 \\
20 \\
28\end{array}$ & $\begin{array}{r}6.7 \\
12.9 \\
10.5 \\
25.6\end{array}$ & $\begin{array}{r}6 \\
18 \\
52 \\
109\end{array}$ & $\begin{array}{r}1.64 \\
2.97 \\
6.50 \\
12.12\end{array}$ & $\begin{array}{r}89 \\
140 \\
497 \\
424\end{array}$ \\
\hline I.R. & 212.75 & 70 & 12.6 & 185 & 6.93 & 1150 \\
\hline
\end{tabular}

It was possible this winter to compare the relative efficiency of fixed-versus rotor-winged aircraft for counting moose in dense coniferous cover. Five plots were counted first with a conventional aircraft ( $90 \mathrm{hp}$. Aeronca Champion), piloted by Murray, and then by helicopter* with Wolfe as the observer. It should be noted that Murray served in the capacity of both pilot and observer. Practically no time elapsed between successive counts, and light conditions as well as the degree of air turbulence were optimal, thus minimizing other variables. The Champ was flown in its usual pattern of tight overlapping circles at an air speed of $85-90 \mathrm{mph}$. and an average elevation of 400 feet. Although slightly higher than normally flown during the actual census, this elevation was maintained to preclude alarming the moose and causing them to leave the plot. The helicopter was flown in overlapping strips at approximately 250 feet and 20-25 mph.

The results obtained by the two procedures were identical on three plots and the overall efficiency of the fixed-winged aircraft was 88 percent of that with the helicopter, based on the total number of moose observed on all five plots. It is impossible to ascertain what percentage of the number of moose actually present on a given plot were missed with the helicopter. In the case of one plot each count missed a different moose of the four animals known to be present. In summary we believe that the extent of the individual observer's experience in moose counting may be more important than the type of aircraft employed. In this respect it is noteworthy that Murray had at least five winters of such experience prior to this year and Wolfe two winters. Furthermore the pilot and the observer complement each other in the actual census operation. These factors could account in part for the approximate 30 percent yealy increase in the number of moose seen on the same plots since 1967 and the resultant higher population estimates of the past two winters.

* Three hours of helicopter time were contributed, courtesy of Metro-Goldwyn-Mayer and the Canadian Film Board. 
Sex, age, and condition of moose killed by wolves

It was possible to examine only 19 of the 30 moose kills found during the 1969 winter study. Nine, or 47 percent, of these were calves of the year and another was a yearling female. Both meteorological and biotic factors probably contributed to the high incidence of calves in this sample. It is probablo that the aforementioned snow conditions made the smaller calves especially vulnerable to attack by wolves. On the other hand the observed high winter calf ratio suggests that more of these animals than usual were available to the wolves. The ratio of males to females among the adult specimens examined was $1.0: 1.25$, respectively. Three of the females exhibited varying degrees of peridontal necrosis, and one old male (\#41) showed a gross deformity of the left scapula; which appeared to have been the result of an old fracture.

Table 3 summarizes data for the adult kills examined. Several of the carcasses were only partially consumed by the wolves and were frozen solidiy into the snow. These conditions impeded a thorough examination of the remains, and in the case of two specimens precluded the removal of tooth material intact for the purpose of age determination. For these reasons, the information in Table 3 must be considered tentative. Some of the missing data will be obtained upon re-examination of carcasses in the coming summer field period. At that time kills not previously investigated will be visited.

Table 3. Adult moose killed by wolves, winter, 1969.

\begin{tabular}{|c|c|c|c|c|c|}
\hline \multirow{2}{*}{$\begin{array}{l}\text { Specimen } \\
\text { number }\end{array}$} & \multirow[b]{2}{*}{ Sex } & \multirow[b]{2}{*}{ Age } & \multicolumn{2}{|c|}{ Patholog.y } & \multirow{2}{*}{$\begin{array}{c}\text { Probable } \\
\text { no. of wolves }\end{array}$} \\
\hline & & & Necrosis & Arthritis & \\
\hline 440 & $f$ & 14 & pending & $?$ & 3 \\
\hline 441 & $\mathrm{~m}$ & 11 & $\ldots$ & - & 2 \\
\hline 442 & $\mathrm{~m}$ & - & $?$ & $?$ & 8 \\
\hline 443 & $f$ & -- & moderate & $?$ & 2 \\
\hline 446 & $f$ & 8 &.- & -- & 3 \\
\hline 451 & f & 17 & advanced & $?$ & 8 or 9 \\
\hline 453 & m & - & $?$ & $?$ & 8 \\
\hline 454 & $\mathrm{~m}$ & 9 & -- & $\ldots$ & 2 \\
\hline 456 & $\mathbf{f}$ & 9 & -- & -- & 8 \\
\hline
\end{tabular}

Investigations of moose mortality patterns

Work was initiated two years ago to reasess the ages of all moose specimens collected to date by means of cementum annulation counts on sectioned molariform teeth. The ages of 276 adult moose determined by this method provide the basis for a refined analysis of mortality patterns and their relationship to various otber biological parameters such as sex and pathology. A few of the more important findings of these investigations are summarized. 
The new age information has been employed to construct a composite ife table for Isle Royale moose. This and the corresponding mortality and survivorship curves are shown in Table 4 and figures 1 and 2 , respectively. Computations are based on the age at death of 374 moose dying of all natural causes on Isle Royale within the past 20 or so years. The unique characteristic of this analysis is the fact that it portrays the vital statistics of a moose population under a natural regime of wolf predation. A high proportion of the moose in this sample undoubtedly were killed by wolves, and the selective nature of this predation is well illustrated by the mortality and survivorship curves. The mortality rate declines sharply after initial heavy losses in the first year and does not begin to increase significantly again until about the seventh year of life. The high survival rate in this relatively invulnerable intermediate age group is shown by the flattened segments of both curves.

These studies will be pursued further in the coming year. The construction of sex-and time-specific life tables might be employed to reveal differences in mortality between sexes or between animals dying in various seasons or during different time periods. Such differences may not otherwise be evident on the basis of conventional statistical approaches alone.

The method of age determination described above has been useful in evaluating. - relationships between age and the vulnerability of moose to certain diseases. Two bone pathologies, peridontitis and degenerative joint disease (arthritis), have been given particular consideration in this respect. The relationship of age distribution to the incidence of these two diseases in Isle Royale moose is shown in Tables 5 and 6.

Table 5. Age distribution of 186 moose 2 years or older at death as related to incidence of peridontal necrosis.

Age in

years

\begin{tabular}{r} 
\\
\hline 2 \\
3 \\
4 \\
5 \\
6 \\
7 \\
8 \\
9 \\
10 \\
11 \\
12 \\
13 \\
14 \\
15 \\
16
\end{tabular}

Total

\begin{tabular}{rrrrrrrrrr}
\multicolumn{2}{c}{$\begin{array}{c}\text { Advanced } \\
\mathrm{mm}\end{array}$} & $\mathrm{ff}$ & $\mathrm{T}$ & $\mathrm{mm}$ & $\begin{array}{c}\text { Incipient } \\
\mathrm{ff}\end{array}$ & $\mathrm{T}$ & $\mathrm{mm}$ & $\begin{array}{c}\text { None } \\
\mathrm{ff}\end{array}$ & $\mathrm{T}$ \\
\hline- & - & - & - & - & - & 3 & 0 & 3 \\
- & - & - & - & - & - & 3 & 0 & 2 \\
- & - & - & - & - & - & 3 & 3 & 6 \\
- & - & - & - & - & - & 1 & 2 & 3 \\
- & - & - & - & - & - & 5 & 5 & 10 \\
- & - & - & - & - & - & 3 & 11 & 14 \\
- & - & - & - & - & - & 9 & 4 & 13 \\
0 & 1 & 1 & 1 & 0 & 1 & 9 & 7 & 16 \\
1 & 0 & 1 & 3 & 3 & 6 & 6 & 6 & 12 \\
0 & 2 & 2 & 1 & 1 & 2 & 5 & 11 & 16 \\
2 & 2 & 4 & 5 & 1 & 6 & 5 & 6 & 11. \\
2 & 3 & 5 & 4 & 2 & 6 & 3 & 8 & 11 \\
3 & 2 & 5 & 4 & 4 & 8 & 1 & 1 & 2 \\
0 & 1 & 1 & 1 & 1 & 2 & 2 & 2 & 4 \\
- & - & - & 1 & 0 & 1 & 0 & 2 & 2 \\
8 & 11 & 19 & 20 & 12 & 32 & 57 & 68 & 125
\end{tabular}

Mean age

$12.8 \quad 12.4$

11
12.4

1920

Degree of necrosis 
Table 4. Ccmposite life table for the Is le Royale moose population

\begin{tabular}{|c|c|c|c|c|}
\hline$x$ & & $I_{x}$ & $1000 q_{x}$ & $e_{x}$ \\
\hline $\begin{array}{c}\text { Age } \\
\text { (years) }\end{array}$ & $\begin{array}{l}\text { Number dying in } \\
\text { age interval } \\
\text { out of } 1000 \text { born }\end{array}$ & $\begin{array}{l}\text { Number surviving } \\
\text { at beginning of } \\
\text { age interval out } \\
\text { of } 1000 \text { born }\end{array}$ & $\begin{array}{l}\text { Mortality rate } \\
\text { per } 1000 \text { alive } \\
\text { at beginning } \\
\text { of age interval }\end{array}$ & $\begin{array}{l}\text { Expectation of life } \\
\text { to those attaining } \\
\text { age interval } \\
\text { (in yeers) } \\
\end{array}$ \\
\hline $0-0.5$ & 88 & 1000 & 88.0 & 6.7 \\
\hline $0.5-1.0$ & 190 & 912 & 208.3 & 7.4 \\
\hline $1-2$ & 40 & 722 & 55.4 & 7.7 \\
\hline $2-3$ & 16 & 682 & 25.7 & 7.9 \\
\hline $3-4$ & 13 & 666 & 29.5 & 7.3 \\
\hline $4-5$ & 27 & 653 & 41.3 & 6.4 \\
\hline $5-6$ & 16 & 626 & 25.6 & 5.6 \\
\hline $6-7$ & 43 & 610 & 70.5 & 4.8 \\
\hline $7-8$ & 53 & 567 & 93.5 & 4.1 \\
\hline $8-9$ & 70 & 514 & 136.2 & 3.4 \\
\hline $9-10$ & 75 & 444 & 168.9 & 2.9 \\
\hline $10-11$ & 69 & 369 & 287.0 & 2.4 \\
\hline $11-12$ & 88 & 300 & 293.3 & 1.9 \\
\hline $12-13$ & 70 & 212 & 330.2 & 2.5 \\
\hline $13-14$ & 67 & 142 & 471.8 & 1.1 \\
\hline $24-15$ & 43 & 75 & 573.3 & 0.8 \\
\hline $15-16$ & 21 & 32 & 656.2 & 0.6 \\
\hline $16-17$ & 8 & 11 & 727.3 & 0.5 \\
\hline $17-18$ & 3 & 3 & 1000.0 & 0.2 \\
\hline
\end{tabular}




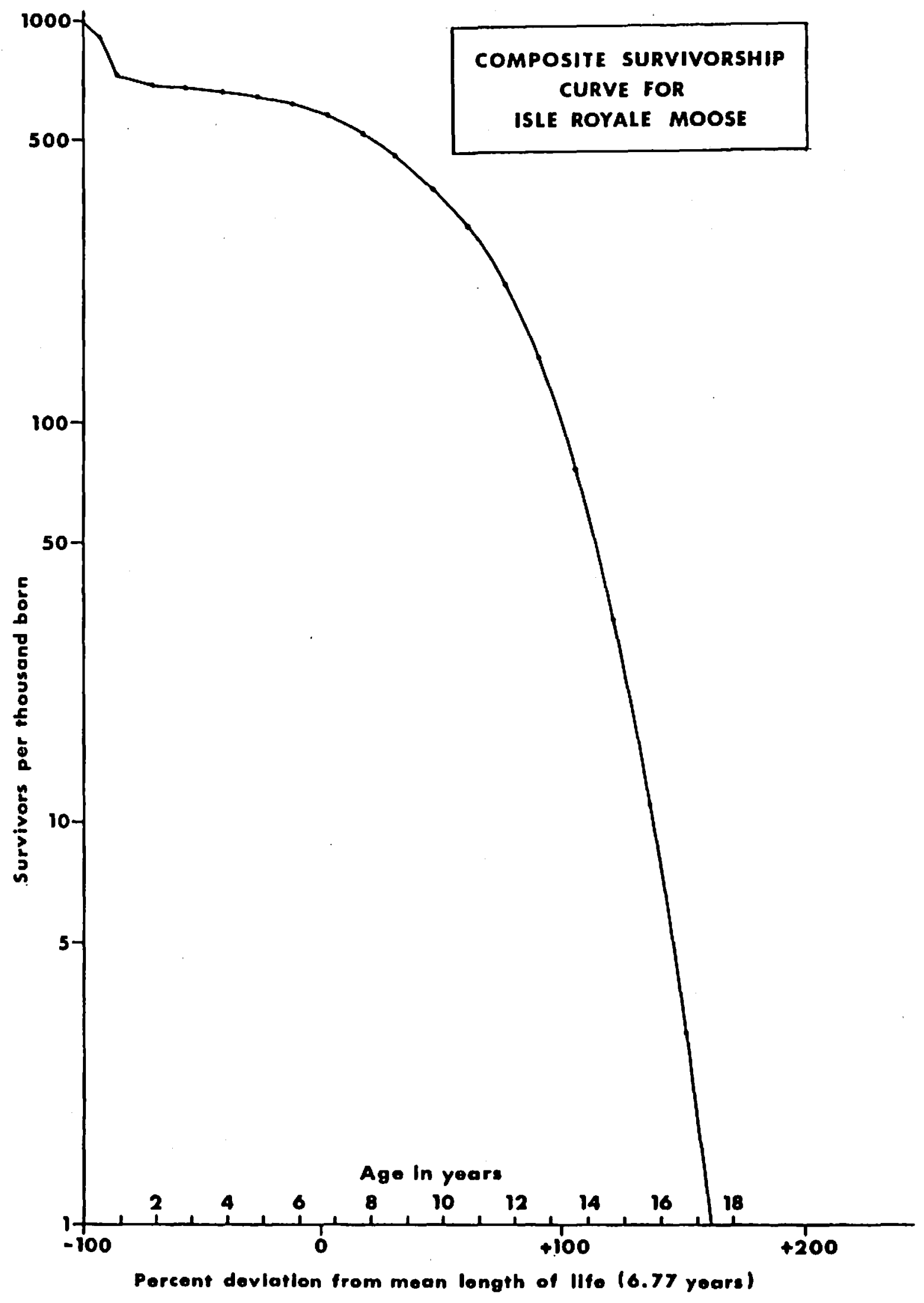



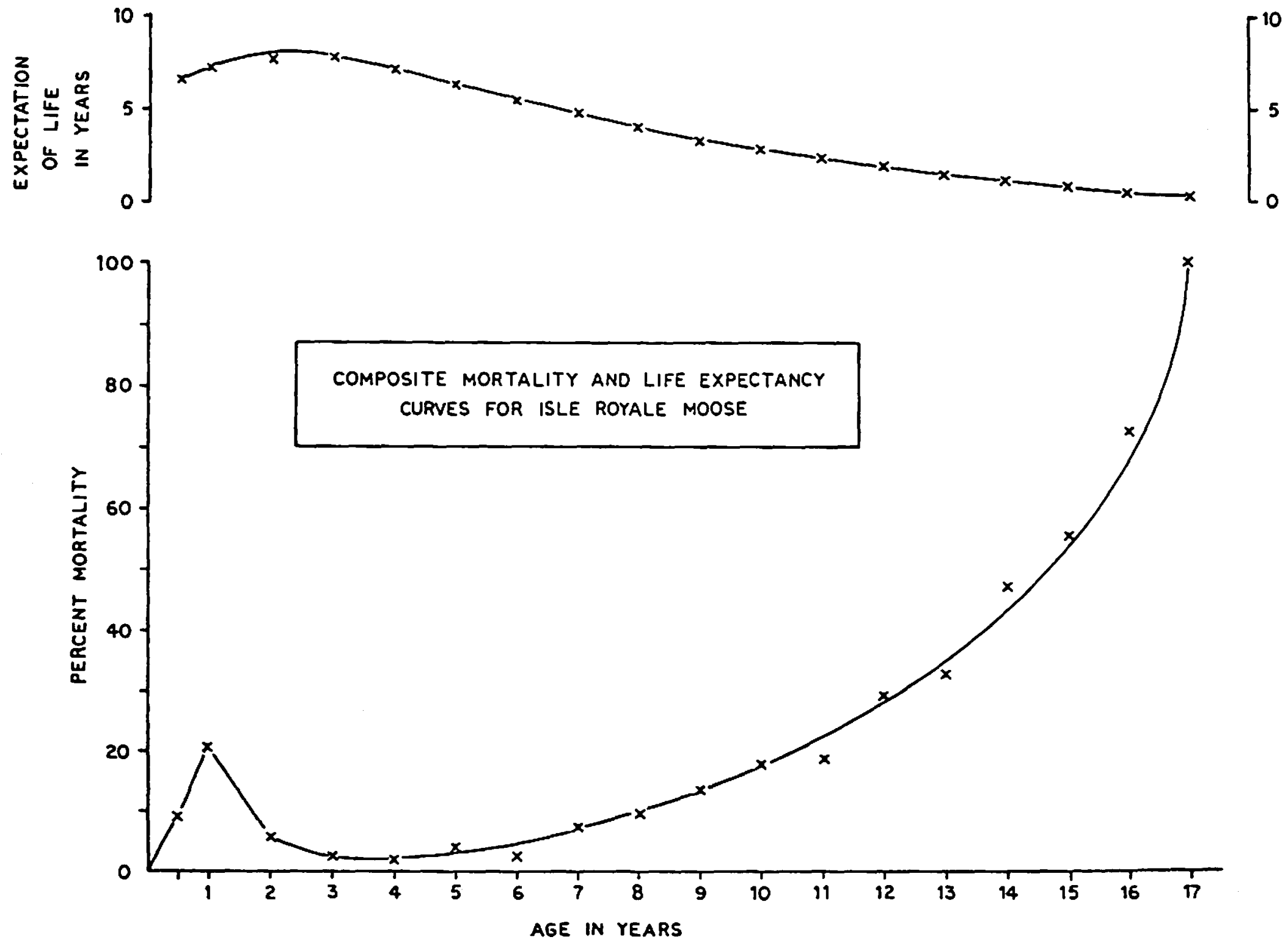
of 186 specimens examined no animals younger than nine years were found with peridontal necrosis, and of those with an incipient condition, 95 percent of the males and 100 percent of the females were ten years or older. Similarly, 88 and 91 percent of the severely necrotic males and females, respectively, comprised individuals of 11 years or older. A highly significant statistical difference $(F=25.70)$ was found to exist between the mean ages of "healthy" and diseased moose as revealed by a two-way analysis of variance. However, the intersex variations are not statistically significant.

Table 6. Age distribution of 77 moose 3 years or older at death as related to incidence of degenerative joint disease.

Age in

years

$\begin{array}{r} \\ \hline 3 \\ 4 \\ 5 \\ 6 \\ 7 \\ 8 \\ 9 \\ 10 \\ 11 \\ 12 \\ 13 \\ 14 \\ 15 \\ 16 \\ \hline\end{array}$

Total

Mean age

Degree of arthritis

\begin{tabular}{|c|c|c|c|c|c|c|c|c|}
\hline \multicolumn{3}{|c|}{ Advanced } & \multicolumn{3}{|c|}{ Incipient } & \multicolumn{3}{|c|}{ None } \\
\hline $\mathrm{mm}$ & $\mathrm{ff}$ & $\mathrm{T}$ & $\underline{\mathrm{mm}}$ & ff & $\mathrm{T}^{\prime}$ & $\mathrm{mm}$ & ff & $\underline{T}$ \\
\hline - & - & - & - & - & - & 0 & 1 & $I$ \\
\hline- & - & - & - & - & - & $I$ & 2 & 3 \\
\hline- & - & - & - & - & - & 1 & 0 & 1 \\
\hline - & - & - & - & - & - & $i$ & 3 & $\overline{4}$ \\
\hline - & - & - & - & - & - & 2 & 2 & 4 \\
\hline 1 & 0 & 1 & 0 & 0 & 0 & 3 & 1 & 4 \\
\hline 1 & 0 & 1 & 1 & 0 & 1 & 3 & 1 & 4 \\
\hline 1 & 1 & 2 & 0 & 1 & 1 & 2 & 1 & 3 \\
\hline 0 & 0 & 0 & 0 & 1 & 1 & 3 & 4 & 7 \\
\hline 1 & 0 & 1 & 2 & 0 & 2 & 5 & 3 & 8 \\
\hline 3 & 0 & 3 & 0 & 0 & 0 & 1 & 6 & 7 \\
\hline 1 & 0 & 1 & 1 & 1 & 2 & 3 & 2 & 5 \\
\hline 0 & 1 & 1 & 0 & 0 & 0 & 2 & 4 & 6 \\
\hline 0 & 0 & 0 & 0 & 0 & 0 & 1 & 2 & 3 \\
\hline 8 & 2 & 10 & 4 & 3 & 7 & 28 & 32 & 60 \\
\hline 11.5 & 12.5 & 11.7 & 11.8 & 11.3 & 11.7 & 10.5 & 10.9 & 10.7 \\
\hline
\end{tabular}

The threshold of vulnerability to the development of an arthritic condition also appears to be age-specific.. Of 77 specimens examined the youngest animal showing signs of the disease was eight years old. There is little difference in the mean ages at death between moose with and without arthritic deformities. Although the sample is small, this suggests that the afflicted animals may be culled from the population soon after developing the condition. 
Wolf numbers, social structure, and predation habits

The absolute minimum number of wolves accounted for during the 1969 winter field period was 15, including one dead adult animal as described below. Associations of 9,3 and 2 wolves, respectively, comprised the living total. No unassociated single wolves, definitely identifiable as such, were observed throughout the six-week study period, but the presence of at least two or three such animals on the island is likely. Hence a more realistic estimate of the actual Isle Royale winter wolf population would be 16-17.

The discrepancy between this estimate and that from the previous winter (23) can be explained by the disappearance of a pack of six wolves-- including two of the original four black animals -. in early February 1968. This group was not seen again during the following summer nor in the current winter study. Considering the fact that the pack in question evidently disappeared in toto and there were reasonably favorable ice conditions at the time, it is probable that it left the island and crossed the ice to Canada.

The dominant pack of wolves on the island this winter was a group of eight or nine animals including one black wolf plus another very dark individual. In this pack were two wolves that appeared to be pups of the previous spring. Thus this group appeared to ve the aggregation of seven seen last winter. When first observed this year the pack consisted of nine animals, but only eight were seen on subsequent occasions. These wolves ranged most of the island with the exception of the extreme northeast quarter. The two smaller groups were not seen to encroach on more than the outermost fringes of this area. At least eight and probably 11 of the $19 \mathrm{kills}$ attributable to this pack were calves of the preceeding spring; the latter figure represents 57 percent of the known kills. By comparison, calves comprised only 33 jercent of the kills made by the smaller associations. The pack of eight also killed one yearling female. We have no basis on which to account for the higher incidence of calves taken by this group except that snow cover was heavier toward the west end of the island.

Information on movements of the two smaller packs is limited. Most sightings of the three were in the area between the east end of Siskiwit Lake and the head of Moskey Basin. The rcmaining duo appeared to confine its activities to the north side of the northeast quarter of the island.

It is noteworthy that the utilization of kills by all three groups was less intensive than in other years. All of the adult carcasses examined during the winter study were only partially consumed and a few were only about half eaten. It appeared that the prevailing snow conditions made a more complete utilization of the carcasses difficult. Accordingly, it is our opinion the wolves-- both the large and smaller packs-- had little difficulty killing moose and found it easier to kill another animal rather than dig out the remains of carcasses frozen into the solid lower layers of snow. The smaller calves probably were consumed before the carsass had a chance to freeze into the snow. These remains may well provide an important source of food for the wolves during the current pre- and post-partuition period and thus prove to be a positive factor in the early survival of pups in the coming year. 


\section{Wolf mortality}

A dead wolf was seen from the air on the north shore of Chippowa Har:on on February 1, 1969. Upon retrieval the following day, the carcass of an aciult $\mathrm{male}$ weighing 81 pounds was found to be intact and only partially frozen. It can be assumed, therefore, that the animal had been dead for less than 24 hours when first seen. Although covered by light snow, both the site and the carcass suggested that the wolf had met a violent death. This was confirmed by a thorough necropsy under the direction of Dr. Harvey J. Olander of the Furdue University Animal Disease Diagnostic Laboratory.

There were numerous puncture wounds in the superficial muscles of the animal's body, which were associated with extensive hemorrhage in the adjacent muscle. The most severe of these was a puncture in the ventral neck region, which severed the carotid artery and the jugular vein as well as fracturing and piercing the larynx. The latter wounds were continuous with an air filled cavity in the neck, that had caused separation of the muscle in that area. Fat cistribution in and around the visceral organs was generally good but the stomach and intestines contained no food material. Large numbers of Echinococcus, one: Taenia sp. and one round worm-- possibly an immature ascarid-- were found in the small intestine. Two of the animal's ribs had been fractured and healed. The left scapulohumeral and coxofemoral joints contained a pus-like fluid, but the synoveal linings were normal. It is probable that this suppurative arthritis had reduced the wolf's mobility, especially under existing snow conditions, and may have been the indirect cause of death.

The number and extent of the wounds described indicate that this wolf was killed by several others. We believe that the pack of eight was responsible. Shortly before the dead animal was discovered, they were sighted only about three miles away, at the east end of Siskiwit Lake, and they were back trackeri to the vicinity of the kill. Whether or not the dead wolf was one of their $0: i: 1$ members or had belonged to another group is not certain. It is our opinion, however, that it had been associated with the pack of three, since this grovip occupied the same area of the island frequented by a pack of four in 1968. 
The Terrestrial Small Mammal Community

As stated in the 1967-68 Annual Report, a portion of the field plans for 1968 were to collect larger samples of snowshoe hares to obtain more reliable information on natural history and numbers. The program designed for red squirrels and deermice was continued, with emphasis on filling gaps in previous knowledge of their breeding patterns, densities and habitat preferences. All aspects of the field research were terminated in October. Trapping sites have been permanently marked for future reference.

$\underline{\text { Red }} \underline{\text { fox }}$

Incidental live-trapping of four foxes and four animals collected for necropsy have yielded body weights and measurements indicating that this subspecies probably is Vulpes fulva rubricosa. This is the fox occurring on the adjacent mainland. Since no satisfactory method has been developed for counting foxes on Isle Royale, studies of this secondary carnivore have been largely restricted to a seasonal gathering of dropping (scats) for an analysis of food habits. This information has particular pertinence to the work on small prey animals.

Table 7 summarizes the occurrence, principally by months in the werm season, of food items identified in 1965 fecal specimens collected during three years. In periods when the sample is sufficiently large, the incidence of occurrence of a particular food in the total number of occurrences probably indicates relative importance.

Mammalian occurrences were highest ( 94.7 percent) during winter and prevalent throughout the year except for August and September. A relatively small winter collection indicates that hares are the main food, with deermice and moose (carrion) being significant secondary items.

The importance of carrion has been noticed since the beginning of the Purdue winter studies. It has been commonly observed that when wolves are not present at a moose carcass foxes move in to feed. This food source probably is most important in years when snowshoe hare numbers are low or when weather conditions are unfavorable for hunting. Field observations show that another winter food that occurs sporadically is the fruit of mountain ash Sorbus (americanus). These fruits may be dropped and buried in snow, to be used by foxes as they are uncovered in warmer weather.

In spring the diversity of the fox diet increases. Birds (possibly carrion) become important as food, as do hares, muskrats, red squirrels, and deermice. Insects, fish, and plant material also appear in scats although they are less frequently found than the above.

The incidence of red squirrels and deermice increases in June and July, perhaps correlated with the young leaving the nest. Plant resources also become more important as fruits ripen. 
Table 7. Isle Royale red fox scat analysis, 1966-68.

\begin{tabular}{|c|c|c|c|c|c|c|c|c|c|}
\hline & winter* & April & May & June & JuIy & August & September & October & $\begin{array}{c}1966-68 \\
\text { Total } \\
\end{array}$ \\
\hline No. scats & 13 & 50 & 114 & 36 & 27 & 135 & 62 & 11 & 448 \\
\hline No. food occurrences & 19 & 83 & 194 & 50 & 45 & 243 & 72 & 12 & 627 \\
\hline Food Items & \multicolumn{9}{|c|}{ Percent of Occurrences } \\
\hline Mammals & 94.7 & 56.5 & 56.7 & 82.0 & 51.0 & 3.5 & 12.6 & 58.3 & 37.9 \\
\hline Moose & 10.5 & 1.2 & 3.1 & 4.0 & 4.4 & - & - & - & 0.2 \\
\hline Beaver & - & - & 1.0 & 8.0 & - & - & - & - & 0.1 \\
\hline Muskrat & 5.3 & 10.8 & 12.9 & 20.0 & 8.9 & - & 1.4 & 8.3 & 8.3 \\
\hline Snowshoe Hare & 57.9 & 26.5 & 20.1 & 24.0 & 8.9 & 0.7 & 4.2 & 41.7 & 14.3 \\
\hline Red Squirrel & - & 10.8 & 10.3 & 14.0 & 15.5 & 2.1 & 2.8 & 8.3 & 7.9 \\
\hline Deermouse & 21.0 & 7.2 & 9.3 & 12.0 & 13.3 & 0.7 & 4.2 & - & 7.1 \\
\hline Birds & - & 19.3 & 10.8 & 6.0 & 13.3 & 0.7 & 8.3 & 25.0 & 9.2 \\
\hline Amphibians \& Reptiles & - & 1.2 & 3.1 & 2.0 & 2.2 & - & - & - & 1.4 \\
\hline Fish & - & 2.4 & 2.6 & 2.0 & 6.7 & 7.7 & - & - & 3.6 \\
\hline Insects & - & 6.0 & 11.8 & 2.0 & 11.1 & 0.7 & - & 8.3 & 5.8 \\
\hline Plant Matter & 5.3 & 8.4 & 6.7 & 6.0 & 15.5 & 85.2 & 79.2 & 8.3 & 40.0 \\
\hline
\end{tabular}

* These are scets picked up in spring after exposure by the snow melt. 
The most noticeable change in food habits occurs in mid- to late summer when foxes eat predominantly fruits, particularly wild sarsaparilla (Aralia nudicaulis). For the three-year period, plant matter (fruits) comprised 85.2 and 79.2 percent of the total occurrences for August and September respectively.

It appears that in this area of minimum prey diversity, the red fox is exploiting available prey species to a high degree. The utilization of fruits also appears to be greater than what has been reported on mainland studies.

Snowshoe hare

In the period of this study, 1966-68, hare numbers have been low on Isle Royale, and returns from live-trapping have been correspondingly meager. To supplement available data on reproductive biology, 43 hares were collected for autopsy as the field work was drawing to a close in 1968.

A summary of records frcm six livetrap quadrats for three springsummer seasons indicates that juveniles composed less than half the animals caught each year. The percentage of adults taken in the entire study was 58.3 . Variations from one area to another probably reflected the small size of samples. These results demonstrate an obviously low rate of annual increase. Field observations in the long-term study indicated that hares dropped off from an earlier peak to a population low in 1965 or 1966. There appears to have been little, if any, change in numbers through 1968, although a slightly higher proportion of juveniles was caught in this last year.

Another index of low annual recruitment-- evidently a characteristic of post-peak hare populations-- is the high mean age ( 1.85 years) of adults found in the animals collected in 1968. Ages were determined by use of the eye lens weight data published by Keith et al. (Jour. Wildl. Mgmt., 1968). The age distribution of 37 hares necropsied is shown in Table 8 . The absence of a two-year-old cohort in this series indicates low survival of young in 1966 and supports other evidence of a population decline, as referred to above.

Table 8. Age pyramid for 37 necropsied snowshoe hares, 1968.

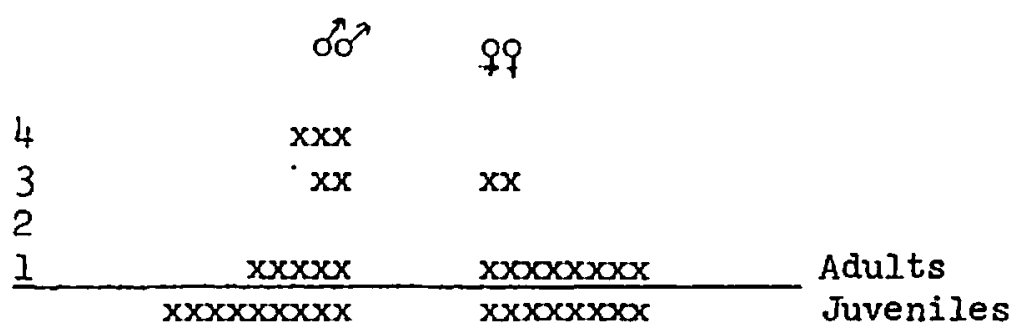


Hare live-trapping on Raspberry Island (Rock Harbor) in the three seasons, 1966-68, indicated that emigration and immigration are factors in stabilizing the population on the small off-shore islands around Isle Royale. Trapping records showed that four male hares moved to the island, evidently during the winter of 1966-67, and a year later two females were found to have arrived there. Because of the small size of Bat Island, 110 yerds to the east, it is most likely that the immigrants came from Smithwick Island, about 220 yards to the west.

Hare density figures are available for two areas of slightly less than 30 acres each. The mature spruce and bog habitat of Raspberry Island supported a late-summer population of nine hares, or 30 per 100 acres in 1968 . In the same year a quadrat of similar size within the area of the 1936 burn (this site is principally alder and jack pine) showed a population of 60 hares per 100 acres. Based on adult hares caught, minimum breeding populations for the two areas were 10 and 23 hares per 100 acres, respectively. These trends are in conformity with figures given in last year's annual report from pellet lines indicating that habitats in the 1936 burn support hare populations two to three times greater than spruce-fir or maple-birch forest types on Isle Royale.

The burned site north of Chippewa Harbor was first trapped in 1962 by Larry J. Roop. Comparisons of hare numbers and hares caught per 100 trap-nights for two trapping periods six years apart are given in Tables 9 and 10 . The much higher density of these animals in 1962 is evident.

Table 9. A comparison of population estimates on the Chippewa Harbor grid between 1962 and 1968 .

\begin{tabular}{|c|c|c|}
\hline Date & $\begin{array}{l}\text { Lincoln - Peterson } \\
\text { index }\end{array}$ & $\begin{array}{l}\text { Density of hares } \\
\text { per } 100 \text { acres }\end{array}$ \\
\hline $\begin{array}{l}\text { August } 17,1962 \\
\text { August } 18,1968\end{array}$ & $\begin{array}{l}39.2 \pm 9.37 \\
18.0 \pm 4.24\end{array}$ & $\begin{array}{r}131.0 \\
60.2\end{array}$ \\
\hline
\end{tabular}

Hares captured per 100 trap-nights (Table 10) also reflect the greater numbers in 1962.

Table 10. Snowshoe hares captured per 100 trap-nights on the Chippewa Harbor grid in 1962 and 1968.

\begin{tabular}{|c|c|c|c|}
\hline & $\begin{array}{l}\text { Hares } \\
\text { captured }\end{array}$ & $\begin{array}{l}\text { Trap- } \\
\text { nights }\end{array}$ & $\begin{array}{l}\text { Hares per } 100 \\
\text { trap-nights }\end{array}$ \\
\hline 1962 & 30 & 336 & 8.93 \\
\hline 1968 & 15 & 786 & 1.91 \\
\hline
\end{tabular}


Hare reproduction: Extrapolated dates of birth were calculated for 29 juveniles handled during the study by using a published estimated age table obtained from hindfoot lengths and body weights (Keith et al.). These results indicated that first litters of the year were born in mid-May and the last litters appeared in late August. Extremely few recaptures made it impossible to follow enough individual animals through the season to determine reliably the number of litters per female. The number of litters per female per year, 1.95, was calculated by finding the total number of days of recognizable pregnancy for all adult females ( 58.5 days) and dividing by 30 which is the number of days that pregnancy is recognizable during the 37-day gestation period.

\section{sites}

Counts of embryos or implantation/of nine adult females gave a mean litter size of 3.33. This figure is about midway between the smaller litters of hares to the south and the larger litters found in northern latitudes. If we use the figure of 2 litters per female per breeding season and a mean litter size of 3.33 , then the average young produced per female per year is 6.49 .

The length of the reproductive season of hares was established from information on 55 adults. Table 11 indicates the initiation and cessation of breeding in 1968. In late February and early March, males come into breeding condition, and by mid- to late March the females are sexually active. Since the last litters are produced in late August, it appears that the total season of reproduction emcompasses about 6 months.

Table 11. Reproductive activity of snowshoe hares, 1968.

Initiation:

Earliest known scrotal testes Feb. 26

Earliest calculated conception date April 1

Earliest calculated parturition date May 8

Termination:

Latest known scrotal testes

Latest calculated conception date

Latest calculated parturition date

Aug. 23

July 21

Aug. 27

Red squirrel

In addition to the live-trapping program, in 1968 a total of 160 animals were collected for necropsy. These yielded information on body weights, age, sex ratio, reproduction, and litter size. A low production of cones in 1968 appeared to have a pronounced effect on the biology of these squirrels. 
The ratio of males to females among 37 juveniles examined over the three-year period did not vary significantly from $1: 1$. Sex ratios for adults also did not show a difference from an even ratio in either the monthly or total samples, except for september when females were predominant.

Age structure of the necropsy semple and live-trapping results were both top-heavy with adult animals. Adults comprised 85.6 percent of 160 animals necropsied from May to October 1968. In 1967 when there was the greatest amount of juvenile recruitment, adults still composed 70.2 percent of the population on the Bangsund and Windigo grids. These age ratios suggest a population that is not rapidly expanding and may actually be declining.

The marking of juveniles in 1967 provided an opportunity to check survival of young animals through their first winter in a good cone year. Eleven of 16 immatures tagged in 1967 were retrapped in 1968, yielding a minimum survival of 68.8 percent of the juveniles. Obviously this is an extremely high rate of survival.

Adult survival was not as good as in juveniles but still high for what usually occurs in small mammal populations. Of 41 adults captured in 1967, 17 ( 41.5 percent) were retrapped in 1968. This figure must be considered minimum, since emigration from the trapping area probably causes an underestimation of the true survival.

There evidently has not been an efficient predator on the Isle Royale red squirrels since martens disappeared in the late 1920's. Less than 8 percent of the total occurrences in 448 fox scats were remains of squirrels, and there is no evidence that any other species takes an appreciable number of squirrels. Disease also does not appear to be an important factor, although squirrels are heavily infested by ectoparasites. One species of tick, two species of mites, and five species of fleas have been collected in the course of this work and identified by Dr. Nixon Wilson of the Bernice P. Bishop Museum. None of the 95 live-trapped squirrels or the animals autopsied showed any signofof gross pathology.

The primary food items are seeds from white and black spruce, balsam fir, and white cedar. Fungi also are important, and squirrels were storing these in 1968 when the cone crop failed. The fluctuation in availability of major food items appears to have a profound effect on the reproductive biology of this species. Why this should occur in the year of failure, rather than in the late winter following a year of failure is not clear. The autopsy data show that most females (about 85 percent) did not conceive in 1968 .

Testis length was greatest in adult males in $1968(17.8 \mathrm{~mm})$ in the February sample. In May the length had decreased to $10.9 \mathrm{~mm}$, and regression continued until August $(7.4 \mathrm{~mm})$. Although testis length is not always a good indicator of the presence of viable sperm, the pattern is noteworthy and suggests that males in 1968 were in breeding condition between February and May. 
The majority of young squirrels handled during this study were from mid- to late June litters. Commonly they were caught for the first time in late July, August, or September. Approximate conception and parturition dates were obtained by using a known gestation period, 38 days, and a daily weight gain figure ( $1.62 \mathrm{gms} . /$ day) frcm information collected on a captive litter of three.

Few individuals from early "spring" litters were found. Evidence from 1966-68 including placental scar counts indicated that only a small number of litters were produced. Rather than two litters per year, as occurs in some populations, the general rule on Isle Royale appears to be one litter per year with most of these being born in June.

The average litter size of these squirrels was approximately three. Data gathered by palpation, and embryo, placental scar, and nest counts on ten litters gave a mean of 3.1. Productivity on these grids was low in 1966 and 1968 but was high in 1967-- a year of good cone production. This evidence indicates that high squirrel productivity is directly correlated with years of good cone yields.

Population densities: As a means of determining the trapped area of each grid, a calculation was made of the average distance between captures within trapping periods. This was determined to be 136 feet on a basis of 162 recaptures. This figure was added to the area bounded by the outer row of traps in a manner similar to that suggested by Brant (1962. Univ. Cal. Pub1. Zool.62:105-184.).

Table 12 gives squirrel densities for both grids. Essentially, densities were the same for 1966 and 1967 . There was a slight drop in 1968, evidently correlated with the lack of juvenile recruitment. These figures suggest that the Bangsund site, a white cedar - speckled alder swamp with inter.spersed ridges of white spruce, balsam fir, white birch, and aspen, supports a greater population than does the upland Windigo area. These densities are higher than most literature reports.

Table 12. Red squirrel densities on the Bangsund and Windigo sites, 1966-68.

\begin{tabular}{cccc}
\hline & \multicolumn{3}{c}{ Squirrels per acre } \\
\cline { 2 - 4 } & $\underline{1966}$ & 1967 & $\underline{1968}$ \\
Bangsund - 16.3 acres & & & \\
all squirrels & 1.65 & 1.65 & 1.47 \\
adults & 0.74 & 1.17 & 1.47 \\
Windigo - 23 acres & & & \\
all squirrels \\
adults
\end{tabular}


Lower densities occur in the sugar maple forest, the 1936 burn, and the century-old burns where there are not large numbers of mature cone-bearing trees. Conifers in the 1936 burn are now reaching maturity and will begin to bear seeds. This increased food supply should raise the carrying capacity of this habitat and increase squirrel densities.

From the above evidence it appears that on Isle Royale, the red squirrel has attained a relatively stable dense population. In the presence of low predation pressure, and adequate habitat, including a usually sufficient food supply, survival rates are high, and the turnover of squirrel biomass is low.

In such a population, as would be expected, the high survival of adults means a low reproductive rate, even in years of favorable food supply. However the situation is more marked in a year of food shortage. Thus, in 1968 the conifers largely failed to bear, and on both the Bangsund and Windigo trapping quadrats (some 30 miles apart) no young were taken. In the collection of animals for autopsy, less than 15 percent were juveniles of the: year. The dynamics of numbers in the Isle Royale red squirrel demonstrate the realities of the carrying capacity limitation and the principle of inversity as applied to reproduction.

\section{Deermouse}

As has been noted in previous reports, Isle Royale presents what appears to be a unique situation for an area of this size (ca. 210 square miles). So far as is known, it supports only one species of mammal smaller than the red squirrel-- the woodland deermouse, Peromyscus $M$. maniculatus. Although the red-backed vole has been reported, no specimen seems to have been preserved, and we have no recent evidence of its presence despite extensive surveys.

Information on the status of the deermouse has been obtained by livetrapping on a grid of 9.34 acres (adjusted trappable acreage) at Conglomerate Bay, plus the operation of snap-trap lines at various locations over the island. Table 13 presents results of the live-trap census for three years. A possible bias, accounting for the increase in 1968, may be that pre-baiting was practiced before the trapping periods in that year.

Table 13. Population estimates and densities for the Conglomerate Bay grid, 1966-68.

\begin{tabular}{|c|c|c|c|}
\hline & 1066 & 1967 & 1968 \\
\hline $\begin{array}{l}\text { Population estimate } \\
\text { (9.34 acres) }\end{array}$ & 21.33 & 34.67 & 38.50 \\
\hline Standard error & 6.16 & 7.08 & 4.20 \\
\hline $\begin{array}{l}\text { Population density } \\
\text { (mice per acre) }\end{array}$ & 2.28 & 3.71 & 4.12 \\
\hline
\end{tabular}


Deermouse density refers to trappable animals.only and does not account for nestlings. Both live-trapping and snap-trapping results (Table 14) indicate that the increase in numbers from 1966 to 1967 was real. Mice per 100 trap-nights for 1968 are not significantly different from those of 1967 . The densities reported here fall within the range of population figures found in mainland studies.

The monthly pattern of mice per 100 trap-nights did differ between 1967 and 1968. Although figures in 1968 were higher in May through July, by August they had dropped below the 1967 level and remained lower through October. The late summer decrease may be correlated with the reduced mast productivity of 1968 .

Table 14. Deermouse snap-trapping results, 1966-68.

$\begin{array}{lrrrrr} & \underline{1966} & \underline{1967} & \underline{1968} & \underline{1966-68} \\ \text { Mice per } 100 \text { trap-nights } & 3.56 & 6.13 & 6.12 & 5.59 \\ \text { Trap lines } & 22 & 35 & 41 & 98 \\ \text { Mice caught } & 126 & 386 & 452 & 964 \\ \text { Trap-nights } & 3543 & 6300 & 7380 & 17,223\end{array}$

The breeding season extends from mid-April to mid-September. In May and June the intensity of breeding was highest, after which it declined during the summer. There does not appear to ve a fall breeding peak. The first subadult mice are taken in traps from mid- to late June. By late June or early July, the first-litter females are breeding.

The mean number of cmbryos of 81 pregnant females examined from 1966 to 1967 was 4.87. An analysis of embryo numbers per pregnent female on a monthly basis indicated that September and October litters may be slightly smaller. The mean litter size of deermice on Isle Royale is about five.

The woodland deermouse inhabiting Isle Royale, subspecies maniculatus, is similar in form and habits to the subspecies occurring in the upper peninsula of Michigan, Peromyscus maniculatus gracilis. It is semi-arboreal and uses its long tail ( 46 percent of adult length) as a balance mechanism.

Most habitat types on the island have been sampled by means of 98 standardized snap-trap lines. In table 15 a comparison is made of trapping results in four major habitats: the climax boreal and hardwood forests, the 1936 burn, and a century-old burn approaching the climax condition. On a basis of mice caught per 100 trap-nights, the greatest density occurs in conifer forests, with the 32-year-old burn and the harciwood forest following in that order. The habitat least productive of this species is the sugar maple - yellow birch woodland-- a mature monotype almost devoid of ground cover. This deermouse is adapted to nearly all of the island vegctation types except those on wet sites. 
Table 15. Deermice per 100 trap-nights in four macrohabitats, 1966-68.

\begin{tabular}{|c|c|c|c|c|}
\hline & $\begin{array}{l}\text { Boreal } \\
\text { forest }\end{array}$ & $\begin{array}{c}\text { Hardwood } \\
\text { forest }\end{array}$ & 1936 burn & $\begin{array}{l}\text { Century- } \\
\text { old burn }\end{array}$ \\
\hline Mice & 456 & 63 & 109 & 275 \\
\hline Trap-nights & 7080 & 1740 & 2332 & 5154 \\
\hline Mice/trap-night & 6.44 & 3.62 & 4.67 & 5.34 \\
\hline
\end{tabular}

Prospects for $1969-70$

During the coming year field work will follow up on the "new" phase of our problem with the wolves and moose. From 1968 (February) to 1969 the wolf population was reduced, evidently through emigration, by about 25 percent. The largest pack in March 1969 was eight. Will the favorable food conditions of last winter (a residue of partially consumed carcasses) contribute to a high reproductive level in the current breeding season? Will the island population build up to about twodozen wolves and then level off, as formerly? Will the longstanding pack of 15-16 be reconstituted by an increase of the pack of eight? The answers to these questions should be forthcoming in about a three-year period.

For the past five years winter counts have indicated an increasing moose population. Either this trend is real, or counts in the early years of this study were short. The situation has been obscured by widely varying winter conditions and patterns of moose distribution-. which in turn produce large human and statistical errors. If moose actually have increased from a level of about 600 in 1960 to 1000 in 1969 , there have been no drastic changes in browse utilization (judged subjectively) to indicate it. A quantitative study of browse consumption and production, properly related to the progress of forest successions, will be complicated by the same distributional factors that confuse the moose census work. It must be a long-term and intensive effort, and this has not been possible in the present program.

In the year ahead, Michael Wolfe will continue to work up information for publication, and he and Allen will bring the wolf population information up to date in a paper after the end of the winter field work. Wolfe will presumably be terminating his three years with the study in the following June. In the period 1970-72, Allen expects to spend much more time in the field and to make the Isle Royale book his major assignment. The winter work will be kept up, but whether or not further graduate studies are undertaken will depend upon the availability of funds and appropriately trained personnel. 
Outlook for $1968-69$

The program for the coming year is much conditioned by the outcome of our studies in 1967-68. Of particular concern are those areas whe re weakness in the fact-finding needs shoring up.

A major problem of the small mammal studies has been obtaining samples sufficiently large for a reasonable measure of statistical reliability. The sampling of populations (low-level in the case of the hare) on an island where transportation must be by boat and hiking trail involves logistic difficulties of a high oräer. Läger samples and more intensive work will be the objective next year. An expuldud collecting job should give additional facts on the breeding biology of this tliree pray species, and in particular the question of the "missing" early littor in red squirrils will be investigated further. Since the winter of 19681 ailc.d to yield satisfactory index of fox numbers, efforts to fill in the trenc will be made in 1969. More information on seasonal food habits will be sought on the fox, as well as its prey. Johnson will begin work on his doctoral thesis after field work is finished at the end of October. An appraisal of results on hand at that time will determine whether the small-mammal phase of the project is to continue another year. Inevitably, this decision also will hinge in part on the state of our funding for 1969-70.

In many respects, the moore-wolf work of the past winter was not comparable with former years. Exceptional circumstances of ten aid interpretation in work of this kind, and this was true in the present case. However, something approaching "normal" weather next February-March would be beneficial in our follow-up on the fate of the black wolves and in determining the ranges and killing rates of the small packs with which we are now dealing. These hoped-for conditions also would permit a check on the exceedingly high moose count of last winter and the changes in moose distribution that seemed to accompany the shallow snow cover and high winds. A special project of the winter of 1970, if frequent fresh snowfall ravors the work, will be the tracking of moose to determine the defecation rate for 24 hours. This figure is needed to interpret the counts of winter pellet accumulation now being obtained on the pellet lines.

As usual, every efrizt will be made in the warm season to expand our sex and age counts of the moose herd and assay herd productivity by means of calf tatios.

Because of conflicting carjgnments, Allen found it necessary to delay the sabbatical leave that had boen plarned for this year. This change in the program, which will make postible more intensive field work in the fall and at other seasons, will be rescheouled as opportunity permits. 